\title{
An Analysis of the Break Points of Structural Rearrangements in Man
}

\author{
PATRICIA A. JACOBS,* KARIN E. BUCKTON, CATHERINE CUNNINGHAM, \\ and MARJORIE NEWTON
}

Medical Research Council, Clinical and Population Cytogenetics Unit, Western General Hospital, Edinburgh

Summary. The distribution of the points of breakage and reunion of a series of 58 Robertsonian translocations, 53 reciprocal translocations, and 10 inversions is described. An excess of 13/14 and 14/21 rearrangements was found among the Robertsonian translocations, this excess being independent of the method of ascertainment of the proband. The distribution of break points between chromosome arms in the reciprocal translocations, with the possible exception of the long arms of chromosome 11, was no different from that expected on the basis of their relative lengths. However, within arms there appeared to be an excess of breaks in the terminal regions, an excess of terminal/centromeric translocations where ascertainment was through a balanced carrier and a possible excess of terminal/median translocations where ascertainment was through an unbalanced carrier. Nine inversions were analysed and three of these involved identical break points on chromosome 8 .

Possible reasons for the apparent non-randomness of points of breakage and exchange are discussed and it is concluded that the techniques of preparation, methods of observations, and methods of ascertainment all affect the distribution of observed points of breakage and exchange and must therefore be taken into cognizance in any study of chromosome rearrangements in man.

The recently developed techniques for banding chromosomes have enabled every chromosome in man to be unequivocably identified and, furthermore, because the banding pattern of any particular segment of a chromosome arm retains its characteristic morphology when transferred to another part of the complement, structural rearrangements within and between chromosomes can be identified with considerable accuracy. Not only can the chromosome arm involved in the rearrangement be determined but, in many cases, the position of the breakpoints can be localized to a single band.

These developments have resulted in two advances in the study of structural abnormalities of the chromosomes. Firstly, they have enabled structural abnormalities previously recognized by simple staining techniques to be accurately classified.

\footnotetext{
Received 2 July 1973.

* Present address: Department of Anatomy and Reproductive Biology, University of Hawaii, Honolulu, Hawaii 96822, USA.
}

Second, they have enabled structural rearrangements to be ascertained which were undetectable when size and arm ratio were the only criteria by which to recognize altered chromosomes. Such aberrations include paracentric inversions, pericentric inversions where the break points are equidistant from the centromere, and reciprocal translocations where the exchanged segments are of approximately equal size. It has been suggested that as many as $75 \%$ of all structural abnormalities in man may fall into those categories unrecognizable on the basis of length and centromere index alone (Jacobs, Frackiewicz, and Law, 1972). The chromosomes of a large number of randomly selected individuals will have to be examined with the banding techniques to determine, with any degree of confidence, the frequencies and significance of previously undetectable structural abnormalities of the chromosomes. However, banding techniques can be utilized immediately to classify with accuracy many of the structural rearrangements of the chro- 
mosomes previously recognized with simple staining techniques.

In the MRC Clinical and Population Cytogenetics Unit in Edinburgh we have, over the past 14 years, recognized a large number of structural rearrangements of human chromosomes utilizing cells from cultures of peripheral blood leucocytes stained with orcein. With the advent of banding techniques we have, wherever possible, re-examined these rearrangements using the fluorescent and/or Giemsabanding techniques. In this report we present the results of our re-examination of those exchanges giving rise to Robertsonian translocations, reciprocal translocations, or inversions.

\section{Materials and Methods}

Between 1958 and 1972 the chromosomes of peripheral blood cultures of over 31,000 individuals have been examined in our laboratory. In all cases the chromosomes were stained with lactic-acetic-orcein and all counting and analysis of chromosomes was done by direct microscopical examination. During that time we recognized 122 independently ascertained structural abnormalities of the autosomes which were shown to be the result of a Robertsonian translocation, a reciprocal translocation, or a pericentric inversion. The chromosome constitution, the method of ascertainment of the 122 probands, and the chromosome constitution of their parents are given in the Appendix in Tables A-F. Investigation of the families of the affected individuals showed on two occasions that two independently ascertained probands were related. A further patient was found to have two translocations, and therefore the total number of rearrangements analysed in the present communication is 121. These consist of 58 Robertsonian translocations, 53 reciprocal translocations, and 10 pericentric inversions.

In order to determine the chromosomes involved in the rearrangements and the position of the break points the cells were stained with quinacrine dihydrochloride and viewed on a fluorescent microscope (O'Riordan et al,
1971) and/or stained with Giemsa after treatment with SSC (ASG technique-Sumner, Evans, and Buckland, 1971). Where appropriate, these techniques were augmented by the centromeric heterochromatin technique (Sumner et al, 1971). In view of the difficulties of obtaining satisfactory ASG-banded preparations from old slides or from preparations previously stained with aceticorcein, fresh blood samples were obtained from the great majority of individuals with a rearrangement. In the event we have been able to identify all but 16 of the original 121 rearrangements. The non-identified rearrangements consisted of eight Robertsonian translocations, seven reciprocal translocations, and one inversion. In the majority of cases where we failed to obtain a repeat blood sample it was because the patient had died and no relatives having the rearrangement were available. Therefore, the unidentified rearrangements almost certainly represent a non-random sample of our total population.

\section{Results}

It must be emphasized that all the rearrangements were originally recognized by direct microscopical examination of orcein-stained preparations. In the great majority of instances the nature of the rearrangement was correctly interpreted on the original preparation. However, on seven occasions re-examination of the rearrangement with the banding techniques showed our original interpretation to be wrong (Table I). Four people were originally thought to have a deletion which was subsequently shown to be a reciprocal translocation; two people were originally thought to have a pericentric inversion which was subsequently shown to be a reciprocal translocation, while all that could be said of the orcein preparation of the remaining patient was that she was missing a chromosome 1 , a chromosome 3, and a C-group chromosome and that these were replaced by three abnormal chromosomes. Her chromosome constitution was subsequently

TABLE I

KARYOTYPES OF SEVEN INDIVIDUALS WRONGLY INTERPRETED ON ORCEIN PREPARATIONS

\begin{tabular}{|c|c|c|}
\hline Registry No.* & Karyotype on Orcein Preparations & Karyotype on Banded Preparations \\
\hline $\mathrm{K} 171 / 214 / 68$ & 46,XX,Ep - & $46, \mathrm{XX}, \mathrm{t}(8 ; 18) \backslash \mathrm{p} 23 ; \mathrm{p} 11)$ \\
\hline $\mathrm{K} 199 / 202 / 70$ & $46, \mathrm{XX}, \mathrm{Cp}-$ & $46, \mathrm{XX}, \mathrm{t}(8 ; 15), \mathrm{p} 11 ; \mathrm{q} 24,25$, or 26$)$ \\
\hline $\mathrm{K} 90 / 233 / 70$ & 46,XY,Dq - & $46, \mathrm{XX}, \mathrm{t}(1 ; 14)(\mathrm{q} 42 ; \mathrm{q} 23)$ \\
\hline $\mathrm{K} 134 / 14 / 71$ & $46, X Y, F ?-$ & $46, X Y, t(3 ; 20)(q 29 ; p 11)$ \\
\hline $\mathrm{K} 189 / 267 / 71$ & $46, X X, \operatorname{inv}(B p+q-)$ & $46, \mathrm{XX}, \mathrm{t}(4 ; 9)(\mathrm{q} 28 ; \mathrm{p} 2)$ \\
\hline $210 / 190 / 71$ & $46, X X, \operatorname{inv}(2 p-q+)$ & $46, X X, t(2 ; 10)(q 11 ; q 22)$ \\
\hline $\mathrm{K} 180 / 48 / 68$ & $46, X X,-1,-3,-C,+B,+\operatorname{mar} 1,+\operatorname{mar} 2$ & $46, \mathrm{XX}, \mathrm{t}(1 ; 3)(3 ; 9), \mathrm{p} 32 ; \mathrm{p} 25,26$ or $27 \mathrm{q} 21 ; \mathrm{q} 22)$ \\
\hline
\end{tabular}

* All patients are referred to by their number in the MRC Registry of Abnormal Karyotypes. 
interpreted on both fluorescent and ASG preparations as being the result of two separate reciprocal translocations involving three chromosomes.

Robertsonian Translocations. A total of 40 Robertsonian translocations, consisting of $29 \mathrm{D} / \mathrm{D}$ and $11 \mathrm{D} / \mathrm{G}$ translocations, was ascertained through a proband with a balanced karyotype (Appendix, Tables $A$ and $B$ ), while 18 Robertsonian translocations, consisting of two $D / D, 12 \mathrm{D} / \mathrm{G}$, and four $\mathrm{G} / \mathrm{G}$ translocations, were ascertained through a proband with an unbalanced karyotype (Appendix, Table C). The results of the analyses of all 58 translocations are given in Table II.

TABLE II

DISTRIBUTION OF ROBERTSONIAN TRANSLOCATIONS

\begin{tabular}{|c|c|c|}
\hline Type & $\begin{array}{c}\text { Number Ascertained } \\
\text { through Balanced } \\
\text { Proband }\end{array}$ & $\begin{array}{l}\text { Number Ascertained } \\
\text { through Unbalanced } \\
\text { Proband }\end{array}$ \\
\hline $\begin{array}{l}13 / 14 \\
14 / 15 \\
13 / 15 \\
\text { Unanalysed D/D } \\
13 / 21 \\
13 / 22 \\
14 / 21 \\
14 / 22 \\
15 / 21 \\
15 / 22 \\
\text { Unanalysed D/G } \\
21 / 21 \\
21 / 22 \\
\text { Unanalysed G/G }\end{array}$ & $\begin{array}{r}23 \\
\frac{1}{5} \\
\frac{2}{2} \\
5 \\
\frac{1}{2} \\
1 \\
\\
\end{array}$ & $\begin{array}{l}\frac{Z}{2} \\
\frac{1}{10} \\
\frac{1}{1} \\
\frac{1}{1}\end{array}$ \\
\hline Total & 40 & 18 \\
\hline
\end{tabular}

All but one of the identified $D / D$ exchanges were of the 13/14 type while half of the identified D/G exchanges, ascertained through a balanced proband, were of the 14/21 type. Two D/D translocations were ascertained through a proband with 46 chromosomes and the clinical features of trisomy 13 but, because of the death of both probands, identification of the translocation was not possible. Twelve $\mathrm{D} / \mathrm{G}$ and four $G / G$ translocations were ascertained through a proband with 46 chromosomes and the clinical features of Down's syndrome and, as expected, a chromosome 21 was involved in all these rearrangements. Ten of the $12 \mathrm{D} / \mathrm{G}$ translocations were of the 14/21 type while three of the four $G / G$ translocations were between two chromosomes 21 .

In man there are 10 possible types of Robertsonian translocation involving heterologous chromosomes; three $\mathrm{D} / \mathrm{D}$ translocations, six $\mathrm{D} / \mathrm{G}$ translocations, and one $G / G$ translocation. If breakage and reunion to form Robertsonian translocations occurred at random, each translocation should arise with equal frequency. We have compared the observed and expected distribution of translocations between the three classes $D / D, D / G$ and $G / G$ (Table III) and there is clearly a large excess in the $\mathrm{D} / \mathrm{D}$ class, and a deficiency in the other two classes.

When the distribution of translocations within the $D / D$ and $D / G$ classes is examined (Table III) it is clear that there is a large excess of the 13/14 type in the $D / D$ class and an excess of the 14/21 type in the $D / G$ class, this latter excess appearing to be at the expense of the other two types involving a chromosome 21. Among the $12 \mathrm{D} / \mathrm{G}$ Robertsonian translocations ascertained through a proband with Down's syndrome, there is also an excess of the $14 / 21$ class $\left(\chi_{2}^{2}=13.50, \mathrm{p}<0.01\right)$.

When all these data are considered it appears that while $13 / 14$ and 14/21 translocations are found fairly frequently in the population, all other types of Robertsonian translocation are rather rare.

Reciprocal Translocations. A total of 48 reciprocal translocations was ascertained through a proband with a balanced complement (Appendix, Table D), and it has been possible to analyse 42 of these. The position of the 84 breakpoints is shown in Fig. 1 and the distribution of the break points by chromosome arm is shown in Table IV, together with the distribution expected if the break points had

TABLE III

COMPARISON OF OBSERVED AND EXPECTED FREQUENCIES OF HETEROLOGOUS ROBERTSONIAN TRANSLOCATIONS ASCERTAINED THROUGH BALANCED CARRIERS

\begin{tabular}{l|c|c|c|c|c|c|c}
\hline Class & Obs & Exp & $x^{2}$ & Type & Obs & Exp & \multicolumn{1}{|c}{$x^{2}$} \\
\hline D/D & 28 & 12 & $x_{2}^{2}=33 \cdot 18$ & $13 / 14$ & 23 & 8 & $\chi_{2}^{2}=42 \cdot 25$ \\
D/G & 11 & 24 & $14 / 15$ & 1 & 8 & $\mathrm{~s}$ \\
G/G & 0 & 4 & $\mathrm{p}<0.001$ & $13 / 15$ & 0 & 8 & $\mathrm{p}<0.001$ \\
& & & & $13 / 21$ & 0 & 1.67 & \\
& & & & $13 / 22$ & 2 & 1.67 & \\
& & & & $14 / 21$ & 5 & 1.67 & $\chi_{2}^{2}=12.40$ \\
& & & & $14 / 22$ & 1 & 1.67 & $\mathrm{p}<0.05$ \\
& & & & $15 / 21$ & 0 & 1.67 & \\
\hline
\end{tabular}




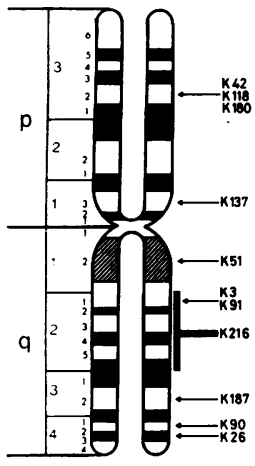

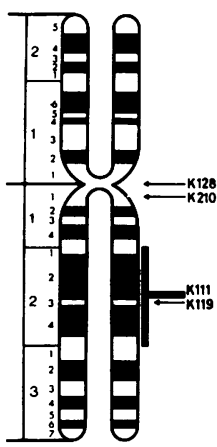

2

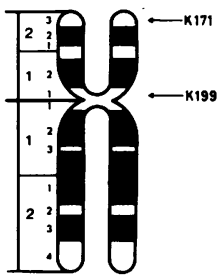

8

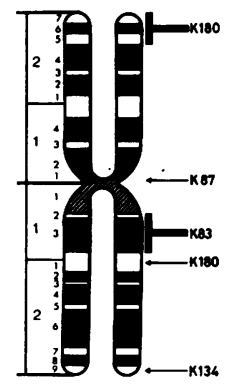

3

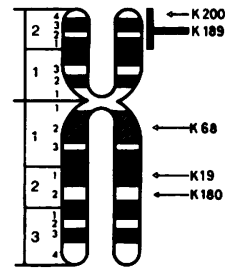

9

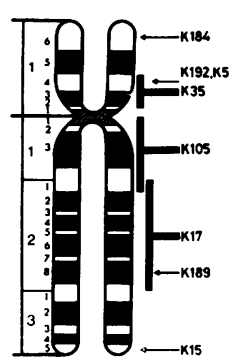

4

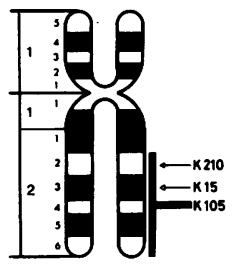

10

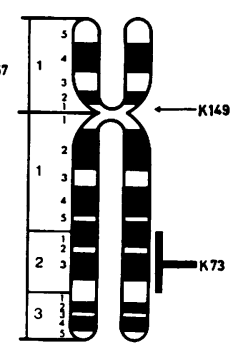

5

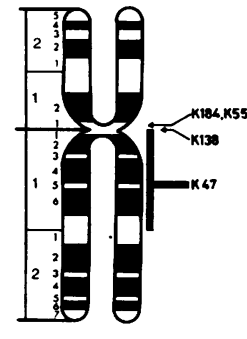

6

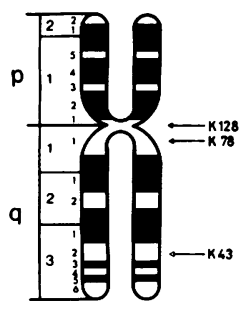

7

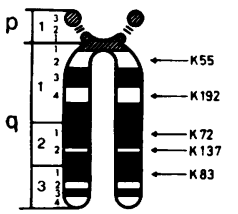

13

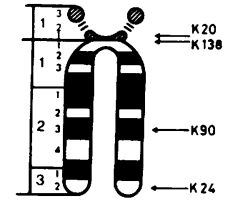

14

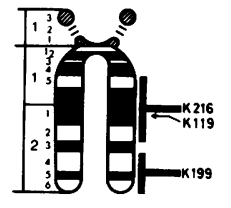

15

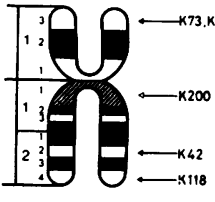

16

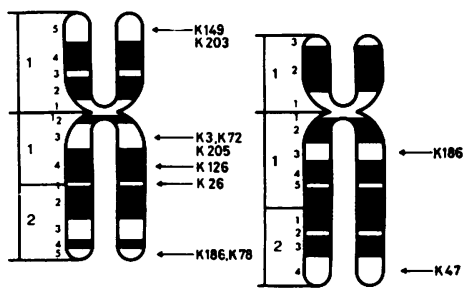

11

12

Fig. 1. Position of the 94 break points involved in the 47 reciprocal translocations analysed. Each translocation is identified by the kindred number in the MRC Registry of Abnormal Karyotypes.

The arrows indicate the band and the bars indicate the areas in which the breaks have occurred.

(Diagrammatic representation of banded chromosomes as in Paris Conference [1971].) 
TABLE IV

DISTRIBUTION OF BREAKPOINTS OF RECIPROCAL TRANSLOCATIONS BY CHROMOSOME ARM

\begin{tabular}{|c|c|c|c|c|c|c|c|c|}
\hline Chromosome & Obs & Exp* & Chromosome & Obs & Exp & Chromosome & Obs & Exp \\
\hline $1 \begin{array}{c}p \\
q\end{array}$ & $\begin{array}{l}4 \\
7 \\
\end{array}$ & $\begin{array}{l}3.2 \\
3.5 \\
\end{array}$ & $6 \begin{array}{l}p \\
q\end{array}$ & $\begin{array}{l}3 \\
1 \\
\end{array}$ & $\begin{array}{l}1.8 \\
2.9\end{array}$ & $13 \begin{array}{l}\mathrm{p} \\
\mathrm{q}\end{array}$ & $\begin{array}{l}0 \\
5 \\
\end{array}$ & $\begin{array}{l}0.5 \\
2.5 \\
\end{array}$ \\
\hline $2 \begin{array}{l}\mathbf{p} \\
q\end{array}$ & $\begin{array}{l}1 \\
3\end{array}$ & $\begin{array}{l}2.5 \\
3.9\end{array}$ & $7 \begin{array}{l}\mathrm{p} \\
\mathrm{q}\end{array}$ & $\begin{array}{l}0 \\
2\end{array}$ & $\begin{array}{l}1 \cdot 7 \\
2 \cdot 6\end{array}$ & $14 \begin{array}{l}p \\
q\end{array}$ & $\begin{array}{l}1 \\
3\end{array}$ & $\begin{array}{l}0 \cdot 6 \\
2 \cdot 3\end{array}$ \\
\hline $3 \begin{array}{l}\mathbf{p} \\
\mathbf{q}\end{array}$ & $\begin{array}{l}2 \\
3\end{array}$ & $\begin{array}{l}2 \cdot 6 \\
2.9\end{array}$ & $8 \begin{array}{l}\mathbf{p} \\
q\end{array}$ & $\begin{array}{l}2 \\
0\end{array}$ & $\begin{array}{l}1 \cdot 3 \\
2 \cdot 6\end{array}$ & $15^{\mathrm{p}} \mathrm{q}$ & $\begin{array}{l}0 \\
3\end{array}$ & $\begin{array}{l}0 \cdot 6 \\
2 \cdot 2\end{array}$ \\
\hline $4 \underset{q}{p}$ & $\begin{array}{l}4 \\
3\end{array}$ & $\begin{array}{l}1 \cdot 4 \\
3.6\end{array}$ & $9 \begin{array}{l}\mathrm{p} \\
\mathrm{q}\end{array}$ & $\begin{array}{l}1 \\
1\end{array}$ & $\begin{array}{l}1 \cdot 3 \\
2 \cdot 5\end{array}$ & $16 \begin{array}{l}\mathrm{p} \\
\mathrm{q}\end{array}$ & $\begin{array}{l}2 \\
2\end{array}$ & $\begin{array}{l}1 \cdot 1 \\
1.6\end{array}$ \\
\hline \multirow[t]{6}{*}{$5 \begin{array}{l}\mathrm{p} \\
\mathrm{q}\end{array}$} & $\begin{array}{l}1 \\
1\end{array}$ & $\begin{array}{l}1 \cdot 4 \\
3 \cdot 4\end{array}$ & $10 \begin{array}{l}p \\
q\end{array}$ & $\begin{array}{l}0 \\
2\end{array}$ & $\begin{array}{l}1 \cdot 2 \\
2 \cdot 4\end{array}$ & $17 \begin{array}{l}\mathbf{p} \\
\mathrm{q}\end{array}$ & $\begin{array}{l}0 \\
4\end{array}$ & $\begin{array}{l}0.9 \\
1.7\end{array}$ \\
\hline & & & $11 \stackrel{p}{p}_{q}$ & $\begin{array}{l}2 \\
7\end{array}$ & $\begin{array}{l}1 \cdot 5 \\
2 \cdot 2\end{array}$ & $18 \begin{array}{l}\mathrm{p} \\
\mathrm{q}\end{array}$ & $\begin{array}{l}1 \\
3\end{array}$ & $\begin{array}{l}0.8 \\
1.6\end{array}$ \\
\hline & & & $12 \underset{q}{p}$ & $\begin{array}{l}0 \\
2\end{array}$ & $\begin{array}{l}1 \cdot 1 \\
2 \cdot 6\end{array}$ & $19 \begin{array}{l}p \\
q\end{array}$ & $\frac{1}{2}$ & $\begin{array}{l}1 \cdot 0 \\
1 \cdot 1\end{array}$ \\
\hline & & & $\times \mathbf{X}_{\mathbf{q}}^{\mathrm{p}}$ & $\begin{array}{l}1 \\
1\end{array}$ & $\begin{array}{l}1.6 \\
1.5\end{array}$ & $20 \begin{array}{l}\mathrm{p} \\
\mathrm{q}\end{array}$ & $\begin{array}{l}1 \\
0\end{array}$ & $\begin{array}{l}1 \cdot 0 \\
1 \cdot 1\end{array}$ \\
\hline & & & & & & $21 \begin{array}{l}p \\
q\end{array}$ & $\begin{array}{l}1 \\
0\end{array}$ & $\begin{array}{l}0.5 \\
1.0\end{array}$ \\
\hline & & & & & & $22 \underset{q}{p}$ & $\begin{array}{l}0 \\
1\end{array}$ & $\begin{array}{l}0.5 \\
1.1\end{array}$ \\
\hline
\end{tabular}

* Based on length measurements, series ' $D$ ' in Paris Conference (1971).

occurred at random. In two instances, where the translocation was a whole arm exchange, it was not certain on which side of the centromere the break had occurred. In both the break points which were considered to be the most likely have been recorded in Table IV. As can be seen from Table IV, the distribution of break points among the chromosome arms is little different from that which would be expected on the basis of their lengths. However, the data available on any one arm are too small to make any meaningful statistical comparison. The long arm of chromosome 11 is the one in which the observed frequency differs most widely from the expected, seven breaks being observed while only 2.2 were expected. However, as can be seen from Fig. 1, the seven break points in $11 \mathrm{q}$ are distributed over four bands. There are three breaks located in band $11 \mathrm{q} 13$, and this is the only band in the complement where more than two breaks have been unequivocably located in our material. However, this is a fairly large band and on these limited data this finding cannot be considered as very convincing evidence of clustering.

The distribution of the observed breaks with respect to the centromere was then examined. For this purpose the chromosome arm was divided into three regions. The centromeric region (consisting of the band immediately proximal to the centro- mere), the terminal region (consisting of the most distal recognizable band), and the remaining median region. With the ASG and fluorescence techniques we can recognize 297 bands in an X haploid complement, which is somewhat fewer than the total number of bands enumerated in the report of the Paris Conference (1971) which takes into account R-banding. Forty-six of the bands we can recognize are centromeric, 46 are terminal, leaving 205 bands in the median region. If we assume that there is no important difference in the mean size of centromeric, terminal, and median bands, we would expect, if breaks occur at random, that the number of breaks in each category would be directly proportional to the number of bands in each category.

We classified the 84 break points involved in our 42 translocations as being either terminal, median, or centromeric. Certain small chromosome arms consist of only one band (eg, 18p). If a break occurred in such a situation it was scored as 0.5 terminal and 0.5 centromeric breaks. Furthermore, when a break had been localized to an area of chromosome arm rather than a single band, and when this area spanned two differently classified parts of an arm, the break was scored as 0.5 in each category involved (eg, K35 on 18q). The distribution of break points within chromosome arms is shown in Table $\mathrm{V}$ and is significantly different from that expected on the 
TABLE V

DISTRIBUTION OF BREAK POINTS WITHIN CHROMOSOME ARMS

\begin{tabular}{l|c|c|c|c}
\hline $\begin{array}{c}\text { Type of } \\
\text { Break Point }\end{array}$ & $\begin{array}{c}\text { Total No. of } \\
\text { Bands }\end{array}$ & $\begin{array}{c}\text { Distribution } \\
\text { of } \\
\text { Break Points }\end{array}$ & $\begin{array}{c}\text { Contribution } \\
\text { to } x^{2}\end{array}$ \\
\hline Terminal & 46 & Obs & Exp & \\
\hline Median & 205 & 46.0 & 58.0 & 5.56 \\
\hline Centromeric & 46 & 16.5 & 13.0 & 0.94 \\
\hline
\end{tabular}

$\chi_{2}^{2}=8.98 ; \mathrm{p}=<0.02$.

basis of length alone, due largely to an excess of break points in the terminal regions.

The three possible interarm positions of break points, as defined above, lead to six possible types of translocation, depending on the position of the two break points involved. In Table VI we have compared the observed distribution of translocations among the six classes with (1) the distribution expected if the 84 break points were distributed according to the respective lengths of chromosome material, and (2) the distribution expected given the observed position of the 84 break points. As can be seen the observed distribution is significantly different from both expected distributions. In the main this is due to an excess of translocations with one terminal and one centromeric break point and a deficit of translocations with one median and one centromeric break point.

It therefore appears that there is an excess of break points in the terminal regions and an excess of translocations involving a terminal and centro- meric break point. There are at least two possible explanations for these observations. Firstly, it may be that there is a non-random distribution of breaks involved in reciprocal translocations, the terminal and centromeric regions being more liable to breakage and exchange than the median regions. Second, it may be that the reciprocal translocations analysed in this communication form a biased sample of all reciprocal translocations. This latter possibility must almost certainly be true as all were recognized from orcein-stained preparations and involve changes in chromosome length or arm ratio. Only a proportion of all reciprocal translocations will be recognizable on non-banded preparations, the recognizable translocations being biased towards those where the difference in length between the two exchanged parts is maximal. The difference will tend to be maximized as the two breaks tend to opposite ends of the chromosome arms, that is, the centromeric and terminal regions. It may be, therefore, that much of the apparent non-randomness of the distribution of the chromosome breaks with respect to the centromere is due to an observational bias rather than true non-randomness of points of breakage and reunion.

We have identified only five reciprocal translocations ascertained through an unbalanced proband, all have been analysed and the 10 break points are shown in Fig. 1. These data are too few to permit any valid analysis; however it is of interest that three of the five translocations involve a chromosome 9 and in two of them the translocation is between a chromosome 9 and a chromosome 22. Where a translocation is ascertained through an unbalanced carrier, there is, in addition to the observational

TABLE VI

DISTRIBUTION OF RECIPROCAL TRANSLOCATIONS BY POSITION OF BREAK POINTS

\begin{tabular}{|c|c|c|c|c|c|c|c|c|c|c|c|c|c|}
\hline \multirow{3}{*}{$\begin{array}{c}\text { Number of } \\
\text { Translocations }\end{array}$} & \multicolumn{12}{|c|}{ Type of Translocation } & \multirow{3}{*}{$x_{5}^{2}$} \\
\hline & \multicolumn{2}{|c|}{$T / T$} & \multicolumn{2}{|c|}{$\mathrm{T} / \mathrm{C}$} & \multicolumn{2}{|c|}{$\mathbf{T} / \mathbf{M}$} & \multicolumn{2}{|c|}{$\mathbf{M} / \mathbf{M}$} & \multicolumn{2}{|c|}{$\mathbf{M} / \mathbf{C}$} & \multicolumn{2}{|c|}{$\mathrm{C} / \mathrm{C}$} & \\
\hline & Obs & Exp* & Obs & Exp & Obs & Exp & Obs & Exp & Obs & Exp & Obs & Exp & \\
\hline 42 & 1 & 1.01 & $9 \cdot 5$ & 2.02 & 10 & 8.98 & 17 & $20 \cdot 01$ & 2 & 8.98 & $2 \cdot 5$ & 1.01 & 一 \\
\hline Contribution to $x^{2}$ & \multicolumn{2}{|c|}{0.00} & \multicolumn{2}{|c|}{$27 \cdot 01$} & \multicolumn{2}{|c|}{$1 \cdot 16$} & \multicolumn{2}{|c|}{0.45} & \multicolumn{2}{|c|}{$5 \cdot 43$} & \multicolumn{2}{|c|}{$2 \cdot 18$} & $\begin{array}{c}36.23 \\
p<0.001\end{array}$ \\
\hline $\begin{array}{c}\text { Number of } \\
\text { Translocations }\end{array}$ & Obs & Expt & Obs & Exp & Obs & Exp & Obs & $\operatorname{Exp}$ & Obs & Exp & Obs & Exp & $x_{6}^{2}$ \\
\hline 42 & 1 & $2 \cdot 75$ & $9 \cdot 5$ & $4 \cdot 23$ & 10 & $11 \cdot 77$ & 17 & $12 \cdot 60$ & 2 & $9 \cdot 03$ & $2 \cdot 5$ & 1.62 & - \\
\hline Contribution to $x^{2}$ & \multicolumn{2}{|c|}{$1 \cdot 11$} & \multicolumn{2}{|c|}{$6 \cdot 57$} & \multicolumn{2}{|c|}{$0 \cdot 27$} & \multicolumn{2}{|c|}{1.54} & \multicolumn{2}{|c|}{$5 \cdot 47$} & \multicolumn{2}{|c|}{0.48} & $\begin{array}{c}15.44 \\
p<0.01\end{array}$ \\
\hline
\end{tabular}

* Theoretical expectation if 84 breaks were distributed among the three classes in proportion to the length of chromosome material in each class.

$\dagger$ Expectation based on the observed distribution of 84 breakpoints among the three classes. 
biases mentioned above, a bias introduced because of selection for viability of the aneuploid segregant. Viability in general is likely to be maximal when the duplication deficiency involves a minimal amount of genetic material. Therefore, viability of unbalanced carriers will be maximized the nearer the break points are to the chromosome tips. However, if both break points are in the terminal regions of the arms the translocation will be difficult to see, especially on non-banded preparations. Therefore, it seems probable that the additional bias introduced when ascertainment is through an unbalanced proband will be towards translocations where one break point is in the terminal region, the other being in the median region. This will produce a translocation which has a high probability of being visible and at the same time one that has a class of aneuploid segregant with a high probability of being viable because it has only a very small deficiency-minimal deficiency presumably being more important for viability than minimal duplication. In this respect it is of interest that four of our five translocations ascertained through an unbalanced carrier are indeed of the terminal/median type, the remaining one being centromeric/median. This is in marked contrast to the figures given in Table VI for the 42 translocations ascertained through a balanced carrier.

Francke (1972) reported, in a series of translocations ascertained through unbalanced carriers an apparent excess of break points in the terminal regions of the chromosomes. As one explanation for her observations she suggested that the translocations might not be reciprocal but might be the result of a single break with joining of the fragment to the telomere of the recipient chromosome. It seems to us that a more realistic explanation for her observation may well be offered by observational and ascertainment biases towards terminal breakpoints.

The distribution of chromosome break points among individuals carrying a structural rearrangement is affected by the position of the initial points of breakage and exchange and by the way selection has acted on the cell or organism carrying the rearrangement. It is impossible, in dealing at the level of the living organism, to avoid the effects of selection, but these effects are minimal among individuals who are mutants for an apparently balanced rearrangement. It is therefore of some interest to compare the distribution of break points among the nine analysed translocations known to be the result of fresh mutations with the 21 analysed translocations known to be inherited. On these limited data there are no obvious differences between the two groups in the distribution of break points either between chromosome arms or within them.

Inversions. A total of nine inversions was ascertained through an apparently balanced proband while one was ascertained through an unbalanced proband who had inherited an inverted chromosome 18 and had in addition, as the result of non-disjunction, an abnormal chromosome which was interpreted as a recombinant chromosome resulting from crossing over in the inversion loop. (Appendix, Table F.) It was possible to analyse nine of the inversions and one was found in each of chromosomes Nos. 1, 2, 3, 5, 18, and 19 . However, all three of the inversions of a C-group chromosome which were analysed were found to involve chromosome 8, and furthermore, in all three the break points appeared to be identical. There are a number of possible explanations for this finding. Firstly, it may be that all three are derived from a common ancestor. We have studied the relatives of all three probands; in two families we have traced the inversion back for two generations and in one for three generations without finding any common ancestor. However, this by no means excludes the possibility of a common origin for these three inversions. Second, bands 8 p32 and $8 \mathrm{q} 11$ may be particularly prone to breakage and reunion. Thirdly, it may be that the possession of this inversion confers some selective advantage on its carriers, although this is not obvious from an analysis of the affected families (Jacobs et al, 1967).

\section{Discussion}

Robertsonian Translocations. The nonrandomness of chromosomes involved in Robertsonian translocations described here confirms the findings of a number of previous reports in which the D-group chromosomes were identified by autoradiography (for review see Cohen, 1971). The excess of 13/14 translocations among D/D translocations has been found previously both among patients ascertained independently of their phenotype and among patients ascertained by reason of a child with a clinical feature of trisomy 13 . The excess of 14/21 translocations among $D / G$ rearrangements ascertained through patients with Down's syndrome has been reported by many groups, but our data shows that an excess of $14 / 21$ translocations is also found among $D / G$ translocations ascertained independently of the phenotype of their carriers.

A number of hypotheses can be advanced to account for the non-randomness of chromosomes 
involved in Robertsonian translocations. However they all fall into one of two general categories which themselves are not mutually exclusive. Firstly, there are those hypotheses which suggest that the different types of Robertsonian translocation arise with very different frequencies (eg, De Grouchy, Crippa, and German, 1970; Hecht and Kimberling, 1971). Second, there are those hypotheses which suggest that the observed differences in frequencies are the result of selection (eg, Rowley and Pergament, 1969; Hamerton, 1970). As more data become available it should be possible to test both hypotheses directly by calculating the mutation rate for every type of Robertsonian translocation.

In this respect it is of some interest to examine the distribution of the karyotypes of Robertsonian translocation among the probands who are known to be mutants. In our material, among the 20 probands ascertained through a balanced carrier where the chromosomes have been identified, and where the karyotypes of both parents have been examined, only three are mutants. However, two of these belong to rare classes; one is the only 14/15 translocation in the $\mathrm{D} / \mathrm{D}$ group and is at the same time the only mutant, while the other has a $15 / 22$ constitution. In contrast, in the data reported by Cohen (1971) there are three mutant heterologous $\mathrm{D} / \mathrm{D}$ translocations where the ascertainment is through a balanced proband, and all three belong to the $13 / 14$ class. These data are clearly too limited to allow us to draw any conclusions.

Reciprocal Translocations. With the possible exception of the long arm of chromosome 11, the distribution of break points by chromosome arm appears to be in agreement with the number expected on the basis of length. The excess of break points and the excess of translocations involving one break point in the terminal and one in the centromeric region may reflect a real excess of points of exchange in these regions or it may be the result of observational bias.

In this respect it is of interest to compare the distribution of break points in reciprocal translocations ascertained through a balanced carrier with that found in aberrations caused by ionizing irradiations. Caspersson and his colleagues (1972) in a preliminary report of the break points produced in vitro by irradiation of human peripheral blood claimed evidence for 'different sensitivity of different parts of one and the same chromosome'. Judging from their figure it appears that in many chromosomes the terminal and centromeric regions show more breaks than the remainder of the chromosome. Seabright (1973) has also published evidence on the distribution of breakpoints in cultures of human peripheral blood irradiated in vitro. She suggests that the number of autosomal breaks is proportional to the length of interband material on trypsin treated preparations but that there is an absolute deficit of breaks in both the $\mathrm{X}$ and $\mathrm{Y}$ chromosomes. Furthermore, she finds a marked paucity of breaks in the distal (or terminal) region of the arms, this deficit applying both to simple breaks and to exchange events. San Roman and Bobrow (1973) studied the distribution of breaks induced both in vivo and in vitro by ionizing radiations. As the results did not differ in the two types of observations they were pooled for analysis. The number of breaks was found to be proportional to chromosome length with the exception of chromosome 3 , in which there was an excess of breaks, and chromosome 16 in which there was a deficit. When the position of breaks within the chromosome arms was analysed there was an excess in the telomeric (or terminal) regions.

An attempt to draw general conclusions on breaks induced by ionizing irradiations from these three papers is difficult, but it does seem that the number of autosomal breaks may well be proportional to chromosome length, and two of the three papers appear to find an excess of breaks in the terminal regions. In both respects these observations are similar to our findings for congenital translocations. As the initial observations on radiation induced rearrangements were made on banded preparations they are free of some, but not all, of the biases which are inherent in our material. The results therefore suggest that there may well be a real nonrandom distribution of the points of breakage and exchange in human chromosome aberrations.

Inversions. The data on pericentric inversions are too few to permit any conclusions to be drawn. However, if our observations with respect to chromosome 8 are confirmed in other populations it will suggest that this particular inversion is fairly widespread in the population.

Before it can be said with certainty whether or not break points associated with structural rearrangements of the chromosome in man are distributed at random, both within and between the chromosomes, many more data are needed. Ideally, if the effects of selection are to be minimal these data should be obtained from an unselected series of newborns carrying balanced rearrangements recognized on banded preparations and who are known to be the result of fresh mutations. As yet, we are a long way from having available adequate data of this type. 
We would like to express our gratitude to all members of the Cytogenetics Section of the Unit, both past and present, without whose efforts the work described in this paper would have been impossible.

\section{REFERENCES}

Caspersson, T., Haglund, U., Lindell, B., and Zech, L. (1972). Radiation-induced non-random chromosome breakage. Experimental Cell Research, 75, 541-543.

Cohen, M. M. (1971). The chromosomal constitution of 165 human translocations involving D group chromosomes identified by autoradiography. Annales de Génétique, 14, 87-96.

De Grouchy, J., Crippa, L., and German, J. (1970). Etudes autoradiographiques des chromosomes humains. VII. Cinq observations de $\mathrm{t}(\mathrm{DqDq})$ familiales. Annales de Génétique, 13, 19-37.

Francke, U. (1972). Quinacrine mustard fluorescence of human chromosomes: characterization of unusual translocations. American fournal of Human Genetics, 24, 189-213.

Hamerton, J. L. (1970). Robertsonian translocations. In Human Population Cytogenetics, ed. by P. A. Jacobs, W. H. Price, and P. Law, pp. 63-75. University of Edinburgh Press, Edinburgh.

Hecht, F. and Kimberling, W. J. (1971). Patterns of D chromosome involvement in human (DqDq) and (DqGq) Robertsonian rearrangements. American fournal of Human Genetics, 23, 361-367.
Jacobs, P. A., Cruickshank, G., Faed, M. J. W., Frackiewicz, A., @ Robson, E. B., Harris, H., and Sutherland, I. (1967). Pericentric (D inversion of a group $\mathrm{C}$ autosome: a study of three families. Annals of Human Genetics, 31, 219-230.

Jacobs, P. A., Frackiewicz, A., and Law, P. (1972). Incidence and mutation rates of structural rearrangements of the autosomes in $\overrightarrow{\bar{c}}$ man. Annals of Human Genetics, 35, 301-319.

O'Riordan, M. L., Robinson, J. A., Buckton, K. E., and Evans, H. J. ఫ (1971). Distinguishing between the chromosomes involved in $\bar{O}$ Down's syndrome (trisomy 21) and chronic myeloid leukaemia $\overline{\bar{C}}$ $\left(\mathrm{Ph}^{1}\right)$ by fluorescence. Nature, 230, 167-168.

Paris Conference (1971). Standardization in human cytogenetics. Birth Defects: Original Article Series, 8, No. 7, 1972. The National Foundation-March of Dimes, New York.

Rowley, J. D. and Pergament, E. (1969). Possible non-random selection of $\mathbf{D}$ group chromosomes involved in centric-fusion $\overrightarrow{0}$ translocations. Annales de Génétique, 12, 177-183.

San Roman, C. and Bobrow, M. (1973). The sites of radiationinduced breakage in human lymphocyte chromosomes, determined by quinacrine fluorescence. Mutation Research, 18, 325331.

Seabright, M. (1973). High resolution studies on the pattern of induced exchanges in the human karyotype. Chromosoma, 40, 333346.

Sumner, A. T., Evans, H. J., and Buckland, R. A. (1971). New technique for distinguishing between human chromosomes. Nature New Biology, 232, 31-32.

\section{Appendix}

\section{TABLE A}

t(DqDq) ROBERTSONIAN TRANSLOCATIONS ASCERTAINED THROUGH BALANCED CARRIER

\begin{tabular}{|c|c|c|c|c|c|}
\hline \multirow[t]{2}{*}{ Registry No. } & \multirow[t]{2}{*}{$\begin{array}{l}\text { Chromosome } \\
\text { Constitution }\end{array}$} & \multirow{2}{*}{$\begin{array}{l}\text { Method of } \\
\text { Ascertainment } \\
\text { of Proband }\end{array}$} & \multicolumn{2}{|c|}{$\begin{array}{l}\text { Parental Chromosomes } \\
\text { Examined }\end{array}$} & \multirow[t]{2}{*}{ Comments } \\
\hline & & & Father & Mother & \\
\hline $\begin{array}{l}\mathrm{K} 183 / 209 / 71 \\
\mathrm{~K} 204 / 151 / 72 \\
\mathrm{~K} 196 / 47 / 72 \\
\mathrm{~K} 206 / 158 / 72\end{array}$ & $\begin{array}{l}45, X X, t(13 q 14 q) \\
45, X X, t(13 q 14 q) \\
45, X Y, t(13 q 14 q) \\
45, X X, t(13 q 14 q)\end{array}$ & $\begin{array}{l}\text { Newborn survey } \\
\text { Newborn survey } \\
\text { Newborn survey } \\
\text { Survey of } 14 \text { year } \\
\text { olds in a general } \\
\text { practice }\end{array}$ & $\begin{array}{l}t(13 q 14 q) \\
t(13 q 14 q) \\
t(13 q 14 q) \\
t(13 q 14 q)\end{array}$ & $\begin{array}{l}\mathbf{N}(\text { ormal }) \\
\mathbf{N} \\
\mathbf{N} \\
\mathbf{N}\end{array}$ & E \\
\hline $\mathrm{K} 32 / 13 / 67$ & $45, X Y, t(13 q 14 q)$ & $\begin{array}{l}\text { Spouse of } \\
\text { individual with } \\
\text { chromosome } \\
\text { abnormality }\end{array}$ & - & - & $\begin{array}{l}\text { Has sibs with same trans- } \\
\text { location }\end{array}$ \\
\hline K16/99/65 & $45, X Y, t(13 q 14 q)$ & $\begin{array}{l}\text { Study of workers } \\
\text { exposed to } \\
\text { ionizing } \\
\text { radiations }\end{array}$ & - & $t(13 q 14 q)$ & - \\
\hline $\mathrm{K} 37 / 205 / 67$ & $45, X Y, t(13 q 14 q)$ & $\begin{array}{l}\text { Twin of patient } \\
\text { with spondylitis }\end{array}$ & 一 & $\mathbf{N}$ & 8 normal sibs \\
\hline $\mathrm{K} 29 / 167 / 66$ & $45, X X, t(13 q 14 q)$ & $\begin{array}{l}\text { Brittle bones and } \\
\text { blue sclera }\end{array}$ & - & - & 4 normal sibs \\
\hline K13/86/64 & $45, X Y, t(13 q 14 q)$ & $\begin{array}{l}\text { Patient with } \\
\text { ankylosing } \\
\text { spondylitis }\end{array}$ & $\mathbf{N}$ & $t(13 q 14 q)$ & - \\
\hline K93/277/69 & $45, X X, t(13 q 14 q)$ & $\begin{array}{l}\text { Survey of patients } \\
\text { with cancer }\end{array}$ & - & $\mathbf{N}$ & - \\
\hline
\end{tabular}


TABLE A-Continued

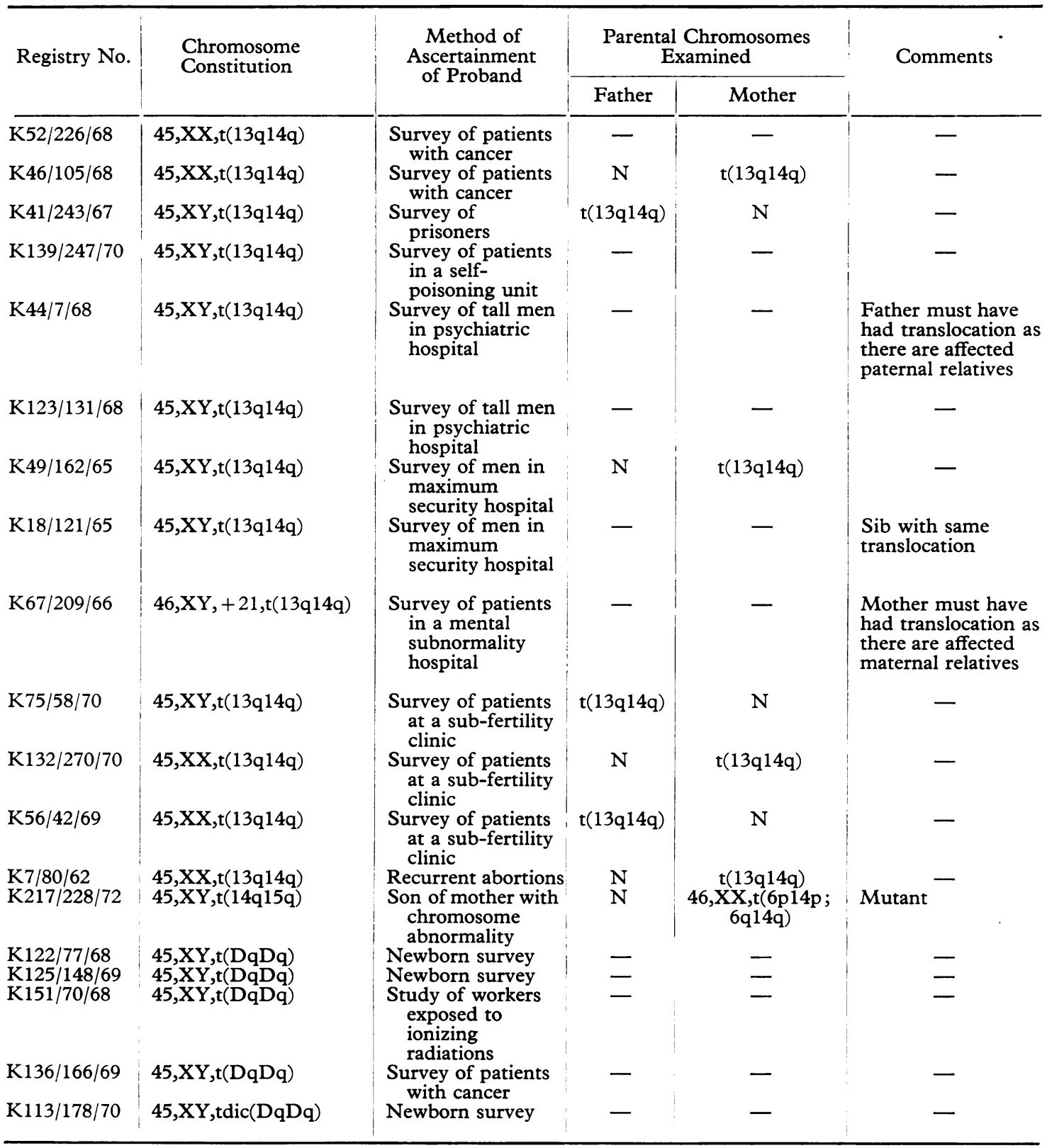


TABLE B

(DqGq) ROBERTSONIAN TRANSLOCATIONS ASCERTAINED THROUGH BALANCED CARRIER

\begin{tabular}{|c|c|c|c|c|c|}
\hline \multirow[t]{2}{*}{ Registry No. } & \multirow[t]{2}{*}{ Chromosome Constitution } & \multirow{2}{*}{$\begin{array}{l}\text { Method of } \\
\text { Ascertainment } \\
\text { of Proband }\end{array}$} & \multicolumn{2}{|c|}{$\begin{array}{l}\text { Parental Chromosomes } \\
\text { Examined }\end{array}$} & \multirow[t]{2}{*}{ Comments } \\
\hline & & & Father & Mother & \\
\hline $\begin{array}{l}\mathrm{K} 185 / 229 / 71 \\
\mathrm{~K} 190 / 281 / 71\end{array}$ & $\begin{array}{l}45, X X, t(13 q 22 q) \\
45, X Y, t(13 q 22 q)\end{array}$ & $\begin{array}{l}\text { Newborn survey } \\
\text { Survey of patients } \\
\text { in a maximum } \\
\text { security hospital }\end{array}$ & $t(13 q 22 q)$ & $\begin{array}{l}\mathbf{N} \\
\mathbf{N}\end{array}$ & 二 \\
\hline $\begin{array}{l}\text { K61/96/69 } \\
\text { K159/173/71 } \\
\text { K107/10/71 }\end{array}$ & $\begin{array}{l}45, X Y, t(14 q 21 q) \\
45, X X, t(14 q 21 q) \\
45, X X, t(14 q 21 q)\end{array}$ & $\begin{array}{l}\text { Newborn survey } \\
\text { Newborn survey } \\
\text { Survey of patients } \\
\text { in general }\end{array}$ & $\stackrel{t(14 q 21 q)}{N}$ & $\stackrel{\mathbf{N}}{\mathbf{N}}$ & $\underset{-}{\text { Mutant }}$ \\
\hline $\mathrm{K} 71 / 197 / 68$ & $45, \mathrm{XX}, \mathrm{t}(14 \mathrm{q} 21 \mathrm{q})$ & $\begin{array}{l}\text { practice } \\
\text { Survey of patients } \\
\text { in a mental } \\
\text { subnormality } \\
\text { hosnital }\end{array}$ & $\mathbf{N}$ & $t(14 q 21 q)$ & - \\
\hline $\mathrm{K} 130 / 92 / 68$ & $45, \mathrm{XX}, \mathrm{t}(14 \mathrm{q} 21 \mathrm{q})$ & $\begin{array}{l}\text { Survey of patients } \\
\text { at a sub-fertility } \\
\text { clinic }\end{array}$ & - & - & - \\
\hline $\begin{array}{l}\mathrm{K} 141 / 107 / 71 \\
\mathrm{~K} 38 / 204 / 67\end{array}$ & $\begin{array}{l}45, X Y, t(14 q 22 q) \\
45, X Y, t(15 q 22 q)\end{array}$ & $\begin{array}{l}\text { Newborn survey } \\
\text { Survey of } \\
\text { prisoners }\end{array}$ & $t(14 q 22 q)$ & $\underset{t(15 q 22 q)}{N}$ & $\overline{-}$ \\
\hline $\mathrm{K} 142 / 384 / 67$ & $45, X Y, t(15 q 22 q)$ & $\begin{array}{l}\text { prisoners } \\
\text { Survey of patients } \\
\text { in a mental } \\
\text { subnormality } \\
\text { hosnital }\end{array}$ & $\mathbf{N}$ & $\mathrm{N}$ & Mutant \\
\hline K94/103/69 & $45, \mathrm{XX}, \mathrm{t}(\mathrm{DqGq})$ & $\begin{array}{l}\text { Survey of patients } \\
\text { with cancer }\end{array}$ & - & - & - \\
\hline
\end{tabular}

TABLE C

(DqDq), (DqGq), AND (GqGq) ROBERTSONIAN TRANSLOCATIONS ASCERTAINED THROUGH UNBALANCED CARRIER

\begin{tabular}{|c|c|c|c|c|c|}
\hline \multirow[t]{2}{*}{ Registry No. } & \multirow[t]{2}{*}{ Chromosome Constitution } & \multirow{2}{*}{$\begin{array}{l}\text { Method of } \\
\text { Ascertainment } \\
\text { of Proband }\end{array}$} & \multicolumn{2}{|c|}{$\begin{array}{c}\text { Parental Chromosomes } \\
\text { Examined }\end{array}$} & \multirow[t]{2}{*}{ Comments } \\
\hline & & & Father & Mother & \\
\hline $\begin{array}{l}\mathrm{K} 117 / 108 / 69 \\
\mathrm{~K} 173 / 97 / 66\end{array}$ & $\begin{array}{l}46, X Y,-D,+t(D q D q) \\
46, X Y,-D,+t(D q D q)\end{array}$ & $\begin{array}{l}\text { Newborn survey } \\
\text { Congenital } \\
\text { abnormalities }\end{array}$ & $\overline{\mathbf{N}}$ & $\begin{array}{l}\mathbf{N} \\
\mathbf{N}\end{array}$ & Mutant \\
\hline $\begin{array}{l}\mathrm{K} 70 / 212 / 68 \\
\mathrm{~K} 157 / 221 / 70 \\
\mathrm{~K} 168 / 279 / 70 \\
\mathrm{~K} 152 / 86 / 61 \\
\mathrm{~K} 2 / 85 / 61 \\
\mathrm{~K} 165 / 175 / 69 \\
\mathrm{~K} 169 / 213 / 68 \\
\mathrm{~K} 33 / 52 / 67 \\
\mathrm{~K} 6 / 73 / 62\end{array}$ & $\begin{array}{l}46, X X,-13,+t(13 q 21 q) \\
46, X Y,-14,+t(14 q 21 q) \\
46, X Y,-14,+t(14 q 21 q) \\
46, X Y,-14,+t(14 q 21 q) \\
46, X X,-14,+t(14 q 21 q) \\
46, X X,-14,+t(14 q 21 q) \\
46, X X,-14,+t(14 q 21 q) \\
46, X Y,-14,+t(14 q 21 q) \\
46, X Y,-14,+t(14 q 21 q)\end{array}$ & $\begin{array}{l}\text { Down's syndrome } \\
\text { Down's syndrome } \\
\text { Down's syndrome } \\
\text { Down's syndrome } \\
\text { Down's syndrome } \\
\text { Down's syndrome } \\
\text { Down's syndrome } \\
\text { Down's syndrome } \\
\text { Down's syndrome }\end{array}$ & $\begin{array}{l}\mathbf{N} \\
N \\
N \\
N \\
t(14 q 21 q) \\
\frac{N}{N}\end{array}$ & $\begin{array}{c}t(13 q 21 q) \\
N \\
N \\
N \\
N \\
N \\
N \\
t(14 q 21 q) \\
t(14 q 21 q)\end{array}$ & $\begin{array}{l}\text { Mutant } \\
\text { Mutant } \\
\text { Mutant } \\
\text { Mutant } \\
\text { Mutant } \\
\text { - } \\
-\end{array}$ \\
\hline $\mathrm{K} 1 / 84 / 61$ & $46, X Y,-14,+t(14 q 21 q)$ & $\begin{array}{l}\text { in } 2 \text { sibs } \\
\text { Down's syndrome } \\
\text { in } 3 \text { sibs }\end{array}$ & $\mathbf{N}$ & $t(14 q 21 q)$ & 一 \\
\hline
\end{tabular}


TABLE C-Continued

\begin{tabular}{|c|c|c|c|c|c|}
\hline \multirow[t]{2}{*}{ Registry No. } & \multirow[t]{2}{*}{ Chromosome Constitution } & \multirow{2}{*}{$\begin{array}{l}\text { Method of } \\
\text { Ascertainment } \\
\text { of Proband }\end{array}$} & \multicolumn{2}{|c|}{$\begin{array}{c}\text { Parental Chromosomes } \\
\text { Examined }\end{array}$} & \multirow[t]{2}{*}{ Comments } \\
\hline & & & Father & Mother & \\
\hline $\mathrm{K} 11 /-/ 63$ & $\begin{array}{c}{[46, \mathrm{XX},-14,+\mathrm{t}(14 \mathrm{q} 21 \mathrm{q})]} \\
\text { presumed; not examined }\end{array}$ & Down's syndrome & $\mathbf{N}$ & $t(14 q 21 q)$ & - \\
\hline $\begin{array}{l}\mathrm{K} 22 / 1 / 66 \\
\mathrm{~K} 147 / 191 / 69\end{array}$ & $\begin{array}{l}\text { 46,XX, }-15,+t(15 q 21 q) \\
46, X X,-21,+t(21 q 21 q)\end{array}$ & $\begin{array}{l}\text { Down's syndrome } \\
\text { Down's syndrome }\end{array}$ & $\underline{\mathrm{N}}$ & $t(15 q 21 q)$ & \begin{tabular}{l}
\multicolumn{1}{c}{-} \\
Must be \\
mutant as \\
has one \\
normal \\
sib
\end{tabular} \\
\hline $\begin{array}{l}\mathrm{K} 143 / 94 / 66 \\
\mathrm{~K} 133 / 79 / 62 \\
\mathrm{~K} 223 / 255 / 72\end{array}$ & $\begin{array}{l}46, X Y,-21,+t(21 q 21 q) \\
46, X X,-21,+t(21 q 21 q) \\
46, X Y,-22,+t(21 q 22 q)\end{array}$ & $\begin{array}{l}\text { Down's syndrome } \\
\text { Down's syndrome } \\
\text { Down's syndrome }\end{array}$ & $\begin{array}{l}\mathbf{N} \\
\mathbf{N} \\
\mathbf{N}\end{array}$ & $\stackrel{\mathrm{N}}{\mathrm{N}}$ & $\begin{array}{l}\text { Mutant } \\
\text { Mutant }\end{array}$ \\
\hline
\end{tabular}

TABLE D

RECIPROCAL TRANSLOCATIONS ASCERTAINED THROUGH BALANCED CARRIER

\begin{tabular}{|c|c|c|c|c|c|}
\hline \multirow[t]{2}{*}{ Registry No. } & \multirow[t]{2}{*}{ Chromosome Constitution } & \multirow{2}{*}{$\begin{array}{l}\text { Method of } \\
\text { Ascertainment } \\
\text { of Proband }\end{array}$} & \multicolumn{2}{|c|}{$\begin{array}{l}\text { Parental Chromosomes } \\
\text { Examined }\end{array}$} & \multirow[t]{2}{*}{ Comments } \\
\hline & & & Father & Mother & \\
\hline $\mathrm{K} 111 / 47 / 69$ & $46, X, t(X ; 2)(q 2 ; q 2)$ & $\begin{array}{l}\text { Survey of patients } \\
\text { at a sub-fertility } \\
\text { clinic }\end{array}$ & - & $\mathrm{N}$ & $\begin{array}{l}4 \text { normal } \\
\text { sibs }\end{array}$ \\
\hline $\mathrm{K} 24 / 60 / 66$ & $46, X, t(X ; 14)(p 11 ; q 32)$ & $\begin{array}{l}\text { Survey of patients } \\
\text { with cancer }\end{array}$ & 一 & - & $\begin{array}{l}\text { Sibs with } \\
\text { same } \\
\text { transloca- } \\
\quad \text { tion }\end{array}$ \\
\hline $\mathrm{K} 180 / 48 / 68$ & $\begin{array}{l}46, \mathrm{XX}, \mathrm{t}(1 ; 3)(3 ; 9)(\mathrm{p} 32 ; \mathrm{p} 25 \text { or } \\
26 \text { or } 27 \mathrm{q} 21 ; \mathrm{q} 22)\end{array}$ & $\begin{array}{l}\text { Survey of patients } \\
\text { in a mental } \\
\text { subnormality } \\
\text { hospital }\end{array}$ & $\mathbf{N}$ & $\mathbf{N}$ & Mutant \\
\hline $\mathrm{K} 3 / 135 / 61$ & $46, \mathrm{XX}, \mathrm{t}(1 ; 11)(\mathrm{q} 21 ; \mathrm{q} 13)$ & $\begin{array}{l}\text { Survey of patients } \\
\text { with cancer }\end{array}$ & - & - & - \\
\hline $\mathrm{K} 26 / 82 / 66$ & $46, X Y, t(1 ; 11)(q 43 ; q 21)$ & $\begin{array}{l}\text { Survey of } \\
\text { prisoners }\end{array}$ & $t(1 ; 11)$ & $\mathbf{N}$ & - \\
\hline $\mathrm{K} 137 / 18 / 67$ & $46, X Y, t(1 ; 13)(p 13 ; q 22)$ & $\begin{array}{l}\text { Survey of patients } \\
\text { in a mental } \\
\text { subnormality } \\
\text { hospital }\end{array}$ & 一 & $\mathbf{N}$ & - \\
\hline $\begin{array}{l}\mathrm{K} 90 / 233 / 70 \\
\mathrm{~K} 216 / 231 / 72\end{array}$ & $\begin{array}{l}46, \mathrm{XY}, \mathrm{t}(1 ; 14)(\mathrm{q} 42 ; \mathrm{q} 23) \\
46, \mathrm{XX}, \mathrm{t}(1 ; 15)(\mathrm{q} 2 ; \mathrm{q} 15 \text { or } 21 \text { or } \\
22)\end{array}$ & $\begin{array}{l}\text { Newboon survey } \\
\text { Newborn survey }\end{array}$ & $\begin{array}{l}\mathbf{N} \\
\mathbf{N}\end{array}$ & $t(1 ; 14)$ & Mutant \\
\hline $\mathrm{K} 42 / 352 / 67$ & $46, X Y, t(1 ; 16)(p 32 ; q 22)$ & $\begin{array}{l}\text { Survey of } \\
\text { prisoners }\end{array}$ & $\mathbf{N}$ & $t(1 ; 16)$ & - \\
\hline K91/135/65 & $46, X Y, t(1 ; 16)(q 21 ; p 13)$ & $\begin{array}{l}\text { Survey of patients } \\
\text { in a maximum } \\
\text { security hospital }\end{array}$ & $\mathbf{N}$ & - & 一 \\
\hline $\mathrm{K} 118 / 119 / 68$ & $46, X Y, t(1 ; 16)(p 32 ; q 24)$ & $\begin{array}{l}\text { Survey of patients } \\
\text { in psychiatric } \\
\text { hospitals }\end{array}$ & - & - & - \\
\hline $\mathrm{K} 51 / 158 / 68$ & $46, X Y, t(1 ; 17)(q 12 ; q 21)$ & $\begin{array}{l}\text { Survey of patients } \\
\text { in a mental } \\
\text { subnormality } \\
\text { hospital }\end{array}$ & $\mathrm{t}(1 ; 17)$ & - & - \\
\hline
\end{tabular}


TABLE D-Continued

\begin{tabular}{|c|c|c|c|c|c|}
\hline \multirow[t]{2}{*}{ Registry No. } & \multirow[t]{2}{*}{ Chromosome Constitution } & \multirow{2}{*}{$\begin{array}{l}\text { Method of } \\
\text { Ascertainment } \\
\text { of Proband }\end{array}$} & \multicolumn{2}{|c|}{$\begin{array}{l}\text { Parental Chromosomes } \\
\text { Examined }\end{array}$} & \multirow[t]{2}{*}{ Comments } \\
\hline & & & Father & Mother & \\
\hline $\mathrm{K} 138 / 3 / 71$ & $46, X X, t(6 p 14 p ; 6 q 14 q) \dagger$ & $\begin{array}{l}\text { Survey of patients } \\
\text { at a sub-fertility } \\
\text { clinic }\end{array}$ & $\mathrm{N}$ & $\mathrm{t}(6 ; 14)$ & 一 \\
\hline $\mathrm{K} 78 / 153 / 70$ & $46, X X, t(7 ; 11)(q 11 ; q 25)$ & $\begin{array}{l}\text { Survey of patients } \\
\text { in general } \\
\text { practice }\end{array}$ & - & - & $\begin{array}{l}\text { Sib with } \\
\text { same } \\
\text { transloca- } \\
\text { tion }\end{array}$ \\
\hline $\mathrm{K} 199 / 202 / 70$ & $\begin{array}{l}46, \mathrm{XX}, \mathrm{t}(8 ; 15)(\mathrm{p} 11 ; \mathrm{q} 24 \text { or } 25 \text { or } \\
\text { (6) }\end{array}$ & $\begin{array}{l}\text { Survey of patients } \\
\text { at a sub-fertility } \\
\text { clinic }\end{array}$ & - & - & - \\
\hline $\mathrm{K} 171 / 214 / 68$ & $46, \mathrm{XX}, \mathrm{t}(8 ; 18)(\mathrm{p} 23 ; \mathrm{p} 11)$ & $\begin{array}{l}\text { Survey of patients } \\
\text { in a mental } \\
\text { subnormality } \\
\text { hospital }\end{array}$ & $\mathrm{N}$ & $\mathrm{N}$ & Mutant \\
\hline $\mathrm{K} 186 / 237 / 71$ & $46, X Y, t(11 ; 12)(q 25 ; q 13)$ & Newborn survey & $\bar{T}$ & $t(11 ; 12)$ & - \\
\hline $\begin{array}{l}\mathrm{K} 72 / 22 / 70^{*} \\
\mathrm{~K} 72 / 178 / 71^{*}\end{array}$ & $\begin{array}{l}46, X Y, t(11 ; 13)(q 13 ; q 21) \\
46, X X, t(11 ; 13)(q 13 ; q 21)\end{array}$ & $\begin{array}{l}\text { Newborn survey } \\
\text { Newborn survey }\end{array}$ & $\begin{array}{l}\mathbf{N} \\
\mathbf{N}\end{array}$ & $\begin{array}{l}t(11 ; 13) \\
t(11 ; 13)\end{array}$ & 二 \\
\hline $\mathrm{K} 203 / 146 / 72$ & $\begin{array}{l}\text { 46,XX,t(11;13)(q13; q21) } \\
46, \mathrm{XX}, \mathrm{t}(11 ; 17)(\mathrm{p} 15 ; \mathrm{q} 11)\end{array}$ & $\begin{array}{l}\text { Newborn survey } \\
\text { Survey of patients } \\
\text { in general } \\
\text { practice }\end{array}$ & $\stackrel{N}{N}$ & $\underline{\mathrm{t}(11 ; 13)}$ & 二 \\
\hline $\mathrm{K} 205 / 152 / 72$ & $46, X X, t(11 ; 17)(q 13 ; q 21)$ & $\begin{array}{l}\text { Daughter of } \\
45, \mathrm{X} / 47, \mathrm{XXX} \\
\text { female }\end{array}$ & 一 & $45, \mathrm{X} / 47, \mathrm{XXX}$ & - \\
\hline $\begin{array}{l}\mathrm{K} 126 / 60 / 71 \\
\mathrm{~K} 20 / 138 / 65\end{array}$ & $\begin{array}{l}\text { 46,XY,t(11;19)(q14;q13) } \\
46, \mathrm{XX}, \mathrm{t}(14 ; 21)(\mathrm{p} 11 ; \mathrm{p} 1)\end{array}$ & $\begin{array}{l}\text { Newborn survey } \\
\text { Congenital } \\
\text { abnormalities }\end{array}$ & $\stackrel{N}{N}$ & $\begin{array}{l}\mathbf{t}(11 ; 19) \\
\mathbf{t}(14 ; 21)\end{array}$ & 二 \\
\hline $\mathrm{K} 175 / 17 / 67$ & $46, X Y, t(19 ; 22)(q 13 ; q 13)$ & $\begin{array}{l}\text { Survey of patients } \\
\text { in a mental } \\
\text { subnormality } \\
\text { hospital }\end{array}$ & $\mathrm{N}$ & $\mathrm{N}$ & Mutant \\
\hline $\mathrm{K} 116 / 73 / 63$ & $46, \mathrm{XX}, \mathrm{t}(1 ; \mathrm{B})(?-; \mathrm{q}+)$ & $\begin{array}{l}\text { Spouse of } 46, \mathrm{XY} / \\
47, \mathrm{XXY} \text { male }\end{array}$ & 一 & - & $\begin{array}{l}3 \text { normal } \\
\text { sibs }\end{array}$ \\
\hline K101/240/70 & $46, X Y, t(1 ; C)(?+; q-)$ & $\begin{array}{l}\text { Survey of patients } \\
\text { with cancer }\end{array}$ & - & - & 一 \\
\hline $\mathrm{K} 127 / 263 / 69$ & $46, X Y, t(B ; B)(q-; q+)$ & $\begin{array}{l}\text { Survey of patients } \\
\text { with cancer }\end{array}$ & 一 & $\mathrm{N}$ & $\begin{array}{l}3 \text { normal } \\
\text { sibs }\end{array}$ \\
\hline $\mathrm{K} 39 / 181 / 67$ & $46, \mathrm{XY}, \mathrm{t}(\mathrm{C} ; \mathrm{C})(\mathrm{q}-; \mathrm{q}+)$ & $\begin{array}{l}\text { Survey of patients } \\
\text { in a mental } \\
\text { subnormality } \\
\text { hospital }\end{array}$ & $\mathrm{N}$ & $\mathrm{t}(\mathrm{C} ; \mathrm{C})$ & - \\
\hline $\begin{array}{l}\mathrm{K} 140 / 26 / 69 \\
\mathrm{~K} 131 / 157 / 68\end{array}$ & $\begin{array}{l}\text { 46,XY,t(C;C)(q+;p-) } \\
46, X Y, t(F ; G)(q+; q-)\end{array}$ & $\begin{array}{l}\text { Newborn survey } \\
\text { Survey of } \\
\text { prisoners }\end{array}$ & $\underline{N}$ & $\underline{N}$ & Mutant \\
\hline
\end{tabular}

* Sibs.

† Describes a whole arm exchange. 
TABLE E

RECIPROCAL TRANSLOCATIONS ASCERTAINED THROUGH UNBALANCED CARRIER

\begin{tabular}{|c|c|c|c|c|c|}
\hline \multirow[t]{2}{*}{ Registry No. } & \multirow[t]{2}{*}{ Chromosome Constitution } & \multirow{2}{*}{$\begin{array}{l}\text { Method of } \\
\text { Ascertainment } \\
\text { of Proband }\end{array}$} & \multicolumn{2}{|c|}{$\begin{array}{l}\text { Parental Chromosomes } \\
\text { Examined }\end{array}$} & \multirow[t]{2}{*}{ Comments } \\
\hline & & & Father & Mother & \\
\hline $\mathrm{K} 15 / 12 / 65$ & $46, \mathrm{XX}, \operatorname{der}(4), \mathrm{t}(4 ; 10)(\mathrm{q} 35 ; \mathrm{q} 23)$ & Congenital & $\mathrm{N}$ & $\mathrm{t}(4 ; 10)$ & - \\
\hline $\mathrm{K} 43 / 279 / 67$ & $46, \mathrm{XX}, \operatorname{der}(19), \mathrm{t}(7 ; 19)(\mathrm{q} 32 ; \mathrm{q} 13)$ & $\begin{array}{l}\text { Survey of patients } \\
\text { in a mental } \\
\text { subnormality } \\
\text { hospital }\end{array}$ & $\mathrm{N}$ & $\mathrm{t}(7 ; 19)$ & - \\
\hline $\mathrm{K} 200 / 103 / 72$ & $46, \mathrm{XX}, \operatorname{der}(9), \mathrm{t}(9 ; 16)(\mathrm{p} 24 ; \mathrm{q} 11)$ & $\begin{array}{l}\text { Congenital } \\
\text { abnormalities }\end{array}$ & $\mathrm{t}(9 ; 16)$ & $\mathbf{N}$ & - \\
\hline $\mathrm{K} 19 / 55 / 66$ & $46, \mathrm{XY}, \operatorname{der}(22), \mathrm{t}(9 ; 22)(\mathrm{q} 21 ; \mathrm{q} 11)$ & Congenital & $\mathrm{N}$ & $t(9 ; 22)$ & - \\
\hline K68/178/69 & $47, \mathrm{XY},+\operatorname{der}(9), \mathrm{t}(9 ; 22)(\mathrm{q} 12 ; \mathrm{p} 1)$ & $\begin{array}{l}\text { Survey of patients } \\
\text { in a mental } \\
\text { subnormality } \\
\text { hospital }\end{array}$ & $\mathrm{N}$ & $t(9 ; 22)$ & - \\
\hline
\end{tabular}

TABLE F

PERICENTRIC INVERSIONS ASCERTAINED THROUGH BALANCED OR UNBALANCED CARRIER

\begin{tabular}{|c|c|c|c|c|c|}
\hline \multirow[t]{2}{*}{ Registry No. } & \multirow[t]{2}{*}{ Chromosome Constitution } & \multirow{2}{*}{$\begin{array}{l}\text { Method of } \\
\text { Ascertainment } \\
\text { of Proband }\end{array}$} & \multicolumn{2}{|c|}{$\begin{array}{c}\text { Parental Chromosomes } \\
\text { Examined }\end{array}$} & \multirow[t]{2}{*}{ Comments } \\
\hline & & & Father & Mother & \\
\hline $\begin{array}{l}\mathrm{K} 212 / 171 / 72 \\
\mathrm{~K} 207 / 161 / 72 \\
\mathrm{~K} 66 / 201 / 69\end{array}$ & $\begin{array}{l}\text { 46,XX,inv(1)(p32q42) } \\
\text { 46,XX,inv(2)(p11q13) } \\
46, X Y, \operatorname{inv}(3)(\mathrm{p} 14 q 27)\end{array}$ & $\begin{array}{l}\text { Newborn survey } \\
\text { Newborn survey } \\
\text { Survey of male } \\
\text { hospital patients }\end{array}$ & $\begin{array}{c}\mathrm{N} \\
\operatorname{inv}(2)\end{array}$ & $\mathrm{N}_{\mathrm{N}}^{\operatorname{inv}}$ & $\overline{\text { 二 }}$ \\
\hline $\mathrm{K} 96 / 82 / 69$ & $46, X Y, \operatorname{inv}(5)(p 13 q 13)$ & $\begin{array}{l}\text { Survey of patients } \\
\text { in a mental } \\
\text { subnormality } \\
\text { hospital }\end{array}$ & - & - & ${ }^{\mathrm{sib}}-$ \\
\hline $\mathrm{K} 4 / 155 / 61$ & $46, X X, \operatorname{inv}(8)(p 23 q 11)$ & $\begin{array}{l}\text { Secondary } \\
\text { amenorrhoea }\end{array}$ & $\mathrm{N}$ & $\operatorname{inv}(8)$ & - \\
\hline $\mathrm{K} 12 / 92 / 64^{*}$ & $46, X Y, \operatorname{inv}(8)(p 23 q 11)$ & $\begin{array}{l}\text { Congenital } \\
\text { abnormalities }\end{array}$ & $\mathrm{N}$ & $\operatorname{inv}(8)$ & - \\
\hline $\begin{array}{l}\mathrm{K} 12 / 77 / 66^{*} \\
\mathrm{~K} 14 / 14 / 65\end{array}$ & $\begin{array}{l}\text { 46,XY,inv(8)(p23q11) } \\
\text { 46,XX, }, \operatorname{inv}(8)(\mathrm{p} 23 \mathrm{q} 11)\end{array}$ & $\begin{array}{l}\text { Survey of prisoners } \\
\text { Congenital } \\
\text { abnormalities }\end{array}$ & $\underset{\mathrm{N}}{\operatorname{inv}(8)}$ & $\underset{\operatorname{inv}(8)}{\mathrm{N}}$ & 二 \\
\hline $\mathrm{K} 82 / 54 / 70$ & $46, X Y, \operatorname{inv}(19)(\mathrm{p} 13 \mathrm{q} 12$ or 13$)$ & Delayed pubertal & $\operatorname{inv}(19)$ & $\mathbf{N}$ & - \\
\hline $\mathrm{K} 80 / 162 / 70$ & $47, \mathrm{XX}, \operatorname{inv}(18)(\mathrm{p} 1 \mathrm{q} 21)$ & Newborn survey & $\mathrm{N}$ & $\operatorname{inv}(18)$ & - \\
\hline $\mathrm{K} 120 / 10 / 69$ & $46, X Y, \operatorname{inv}(C)(p-q+)$ & $\begin{array}{l}\text { Survey of patients } \\
\text { with cancer }\end{array}$ & 一 & - & - \\
\hline
\end{tabular}

* Members of the same family. 